\title{
Uma análise axiológica dos projetos de lei sobre pessoas trans e esporte no Brasil
}

\author{
An axiological analysis of law projects on trans persons and \\ sport in Brazil \\ Rafael Marques Garcia \\ rafa.mgarcia@hotmail.com Universidade \\ Federal do Rio de Janeiro, Brasil \\ https://orcid.org/0000-0002-0837-1493 \\ Erik Giuseppe Barbosa Pereira \\ egiuseppe@eefd.ufrj.br \\ Universidade Federal do Rio de Janeiro, Brasil \\ https://orcid.org/0000-0001-8129-4378
}

Recepção: 05 Maio 2020

Aprovação: 26 Setembro 2020 Publicação: 09 Outubro 2020

Cita sugerida: Marques Garcia, R. y Barbosa Pereira, E. G. (2020). Uma análise axiológica dos projetos de lei sobre pessoas trans e esporte no Brasil. Educación Física y Ciencia, 22(4), e154. https://doi.org/10.24215/23142561e154
Resumo: O presente trabalho objetivou analisar os enunciados de seis Projetos de Lei protocolados em Assembleias Legislativas nacionais que visam regulamentar a participação de atletas trans no esporte brasileiro, mais especificamente quais as bases fundamentalistas utilizadas pelos deputados autores para se posicionarem axiologicamente acerca da temática. Metodologicamente, analisamos nosso material de acordo com a técnica de análise documental. Como resultados, pudemos constatar que todos os projetos se alicerçam em aspectos unicamente biológicos sobre os sexos, apresentam fragilidades teórico-conceituais sobre as identificações e expressões de gênero e sexualidades, propõem como solução esportiva alternativas excludentes e/ou vexatórias ao público de atletas trans que queiram competir no Brasil e não apresentam indicações bibliográficas para as afirmações conclusivas às quais sinalizam. Por fim, desejamos que a presente pesquisa se torne mais uma potente oportunidade de questionar as normas que permeiam a esfera legislativa do/no esporte brasileiro e, assim, revitalizá-lo à luz dos princípios básicos de nossa Constituição.

Palavras-chave: Constituição e Estatutos, Pessoas Transgênero, Sexo, Esportes, Brasil.

Abstract: This work aimed to analyze the statements of six bills of law filed in national Legislative Assemblies that aim at regulating the participation of trans athletes in Brazilian sports, more specifically what fundamentalist bases are used by the deputy authors to position themselves axiologically about the theme. Methodologically, we analyze our material according to the document analysis technique. As a result, we could see that all projects are based on purely biological aspects about sexes, current theoretical and conceptual weaknesses in gender and sexuality identifications and expressions, and propose exclusionary and/or vexing alternatives to the public of trans athletes that want to compete in Brazil. Also, they do not have bibliographic indications for the conclusive statements to which they signal. Finally, we hope that this research becomes another powerful opportunity to question the rules that permeate the legislative sphere of/in Brazilian sport and, thus, revitalize it in the light of the basic principles of our Constitution.

Keywords: Constitution and Bylaws, Transgender persons, Sex, Sports, Brazil. 


\section{Introdução}

No Brasil, as discussões sobre atletas trans ${ }^{1}$ e esporte encontram-se inflamadas desde a contratação da atleta Tifanny Abreu, mulher transexual e jogadora de voleibol, pela equipe do Vôlei Bauru/SP, do interior paulista (hoje SESI/Vôlei-Bauru) no final do ano de 2017. De lá para cá, o desempenho de Tifanny nas quadras suscitou inúmeros questionamentos e investigações científicas e midiáticas, sendo amplamente discutido por pesquisadores/as, estudiosos/as, internautas, atletas e técnicos/as de várias modalidades esportivas.

No ano de 2018, a equipe de Tifanny foi campeã estadual de voleibol e a atleta recebeu o prêmio de melhor jogadora da competição. A esta altura, Tifanny já lidava com críticas de vários setores (gestores/as de clubes, demais jogadores/as, técnicos/as), porém uma das que mais lhe causava desconforto era a incessante investidura da ex-jogadora de voleibol feminino Ana Paula Henkel, que elaborou no corrente ano uma carta $^{2}$ direcionada ao Comitê Olímpico Internacional (COI) criticando a nova política ${ }^{3}$ competitiva adotada pela entidade a partir de 2015 para atletas trans. Ana Paula publicou a carta em um dos veículos informativos online de maior acesso do Brasil, o jornal Estadão ${ }^{4}$, ampliando assim o número de apoiadores à sua causa (que, em suma, resume-se à adoção do sexo biológico como critério para competição nas modalidades esportivas, e não a identificação do gênero aliada aos processos de hormonização).

A partir dessas discussóes, projetos de lei (PL's) passaram a ser elaborados no Brasil por deputados federais e estaduais, atentos às colocações de Ana Paula. A ex-atleta é abertamente contrária à inclusão de atletas trans, principalmente mulheres, em competições oficiais femininas e afirma que é preciso cautela e seriedade para se chegar a um consenso, nomeando a decisão tomada pelo COI em 2015 de apressada e irrefletida.

No ano de 2019, seis PL's foram protocolados em Assembleias Legislativas nacionais, sendo: PL 346/2019, de autoria do deputado estadual Altair Moraes (PRB-SP); PL 331/2019, de autoria do deputado estadual Rodrigo Amorim (PSL-RJ); PL 203/2019, de autoria do deputado estadual João Luiz (PRB-AM); PL 2596/2019, de autoria do deputado federal Julio César Ribeiro (PRB-DF); PL 2639/2019, de autoria do deputado federal Sóstenes Silva Cavalcante (DEM-RJ) e; PL 2200/2019, de autoria do deputado federal Manoel Isidório de Santana Júnior (AVANTE-BA). Todos têm em comum a redação sugerindo como único critério o sexo biológico para a participação de atletas trans no esporte brasileiro. Este último, inclusive, faz menção direta à Ana Paula e a congratula pela iniciativa.

Também, duas audiências públicas foram realizadas pela Comissão de Esporte da Câmara dos Deputados de Brasília para tratar do tema em questão. $\mathrm{Na}$ primeira ${ }^{5}$, em 05/06/2019, o encontro foi marcado por divergências de opiniões sobre a temática. Já na segunda ${ }^{6}$, em 25/06/2019, complementar à primeira edição, chegou-se ao consenso de que não existem estudos científicos suficientes que possam comprovar 
conclusivamente uma vantagem de homens e mulheres trans sobre seus/ suas concorrentes cisgêneros ${ }^{7}$.

Este trabalho averigua, discursiva e politicamente, as medidas legislativas que estão sendo elaboradas no Brasil para tratar sobre pessoas trans no esporte, onde almejamos contribuir com os estudos de gênero e sexualidades na Educação Física e esporte, valorizando eixos críticos sobre a temática em tela, além de desmistificar preconceitos e saberes já arraigados no senso comum com poucas evidências científicas. Assim, desejamos que a presente pesquisa se torne mais uma potente oportunidade de questionar as normas que permeiam a esfera legislativa do/no esporte brasileiro.

Tudo aquilo que produzimos ou enunciamos, enquanto sujeitos sociais, (re)vela marcas constitutivas daquilo que acreditamos e/ou defendemos, ou seja, as nossas produções discursivas deixam rastros de nossos posicionamentos axiológicos (Bakhtin, 2006). A axiologia ${ }^{8}$ consiste em um juízo de valor que, para Carvalho (2003), está presente em todas as esferas organizacionais do mundo. Nesse sentido, o Direito, por conseguinte, as legislações e jurisprudências, valem-se de normas que foram/são construídas a partir da atribuição de valores de quem as propõem, e quando nos inclinamos a discutir sobre a axiologia nesse campo, é importante dizer que toda norma legisladora parte de uma compreensão filosófica de mundo (Carvalho, 2003). A partir disso, compreende-se a própria noção axiológica do discurso enquanto uma extensão filosófico-sociológica de determinados princípios e que, para a análise que iremos propor, torna-se fundamental por apontar como pensam legisladores e como fazem uso do poder axiológico dentro do campo que lhes compete, denunciando, por fim, a correlação íntima entre valores e normas dos próprios legisladores em questão.

O filósofo Mikhail Bakhtin discute sobre a axiologia inicialmente em $O$ autor e o herói na atividade estética ${ }^{9}$ (2006) e no decorrer de suas produções, é possível perceber deslocamentos semânticos em que Bakhtin traz para a dimensão ética - humana - a constituição do sujeito por meio de seus posicionamentos axiológicos, isto é, sempre assumindo posições diante de situações corriqueiras, sejam políticas, históricas, sociológicas ou ideológicas.

Assim, temos por objetivo analisar os enunciados dos seis PL's protocolados em Assembleias Legislativas nacionais que visam regulamentar a participação de atletas trans no esporte brasileiro. Interessa-nos investigar qual(is) fundamentação(ões) é(são) utilizada(s) pelos deputados autores de tais projetos e como os mesmos se posicionam axiologicamente acerca do que já sabemos cientificamente sobre atletas trans e esporte no meio acadêmico (inter)nacional.

\section{Aspectos metodológicos}

Para atingir nossos anseios, realizamos uma pesquisa de caráter qualitativo, utilizando a análise documental como estratégia de 
análise (Cellard, 2008). Para o autor, a adoção desta técnica favorece o processo de maturação de conceitos e ideias através do seguinte percurso metodológico de reflexão: 1- Conceituação e caracterização da pesquisa documental em si; 2- Discussão e ampliação do documento a ser analisado e; 3- Análises e inferências acerca dos princípios investigativos vislumbrados. Neste cotejo, deve-se extrair informações e confeccionar entendimentos que se interconectam com objetivos da pesquisa: "a fim de estabelecer essas ligações e de constituir configurações significativas, é importante extrair os elementos pertinentes do texto, compará-los com outros elementos contidos no corpus documental" (Cellard, 2008, p. 304).

A partir desses traçados iniciais, e seguindo as sugestões do autor, debruçamo-nos sobre esta proposta após elaborar o seguinte roteiro de ações: 1- Acesso teórico do/no projeto; 2- Aprofundamento na leitura proposta; 3- Extração analítica dos escritos que contemplassem nossa empreitada; 4- Amplificação das reflexões e preâmbulos da temática e; 5Registro, organização e ordenação das ideais. Desta forma, como estamos analisando projetos de lei propostos por deputados estaduais e federais, também foi objeto de nossa análise o perfil de cada um desses autores, bem como a caracterização do cenário nacional em que são protocoladas tais ementas.

\section{Resultados e discussão}

Todos os projetos surgem no ano de 2019, dois anos após o Brasil registrar a primeira participação de uma atleta trans no esporte de alto rendimento em terras nacionais (mais especificamente, Tifanny Abreu, pela Superliga Feminina de Voleibol 2017/2018). Em meio a toda repercussão envolvendo sua atuação, inúmeras críticas e opiniões dividiram pessoas de todos os lados, cogitando ideias contrárias e a favor da participação de atletas trans em competições brasileiras.

Para melhor leitura e compreensão de nossos resultados, ordenamolos em categorias com base ao que se propõem a discutir, sendo: 3.1O perfil dos deputados autores, onde discorremos sobre os aspectos legislativos dos idealizadores, resumindo-os no Quadro 1- Síntese das informações dos deputados autores dos projetos (abaixo, p. 7) e; 3.2O texto de cada projeto, onde organizamo-los em dois grandes blocos que apresentam o Quadro 2- Os Projetos Estaduais (abaixo, p. 8), e o Quadro 3- Os Projetos Federais (abaixo, p. 12). Assim, apresentamos nossas interpretações sobre o movimento legislativo nacional que emerge sobre a temática em questão, elaborando também o Quadro 4- Efeitos e tempo esperado dos hormônios feminizantes (abaixo, p. 18) e o Quadro 5- Riscos associados à terapia hormonal feminizante (abaixo, p. 19) para enriquecer o debate. 


\section{1- O perfil dos deputados autores}

À luz de nossa empreitada metodológica, essa seção é importante em termos axiológicos porque é através da caraterização dos autores que podemos encontrar possíveis mecanismos de auxílio em seus posicionamentos discursivos que são apresentados em seus projetos de lei. Essas tomadas de posição ideológicas, por sua vez, nos fazem perceber o quanto há alinhamentos de partidos e de sujeitos que se propõem a fortalecer determinados discursos a fim de concretizar, muitas vezes, desejos pessoais e pontos de vista subjetivistas (Carvalho, 2003; Bakhtin, 2010).

Dito de outra forma, "não há como um objeto estético (artístico ou literário) ser deslocado de sua realidade cultural, semânticoaxiológica, pois perderá seus valores, sua trama dialógica, seus sentidos plurivocais" (Santana, 2018, p. 173). Isso significa que "O vivenciamento de uma postura axiológica consiste na presença constitutiva do outro em mim (outros enunciados que atravessam os discursos os quais profiro)" (Santana, 2017, p. 239). Nessas camadas interpretativas, o objeto de nossa análise para averiguação dos discursos e dos posicionamentos axiológicos são, para além dos PL's, os próprios autores destas propostas.

Os deputados estaduais que já protocolaram PL's para regulamentar a participação de atletas trans no Brasil são: Altair Moraes (PRB-SP); Rodrigo Amorim (PSL-RJ) e João Luiz (PRB-AM). Já entre o grupo de deputados federais estão Julio César Ribeiro (PRB-DF); Sóstenes Silva Cavalcante (DEM-RJ) e Manoel Isidório de Santana Júnior (AVANTEBA).

Altair Moraes é filiado ao partido Republicanos (PRB), desenvolvendo ações nas áreas de segurança pública; defesa e proteção da mulher; saúde; educação; esportes; apoio aos atletas e paratletas; e melhoria da qualidade dos serviços públicos. Nasceu em 1969 em Recife/PE, onde começou a praticar artes marciais durante a infância e se tornou atleta de karatê. Para além do esporte, também sempre esteve envolvido com a religião, dedicando-se por vinte e dois anos ao Evangelho e aos projetos de recuperação da dignidade de pessoas em situação de vulnerabilidade social, moradores de rua e dependentes químicos. Em 2018, foi eleito deputado estadual por São Paulo com 86.230 votos, prometendo apoiar atletas e paratletas, melhorar o serviço público e preservar a célula mater da sociedade: a família cristã. Em suas palavras: "Faço um compromisso público e irrevogável de não fugir à batalha contra o descumprimento da lei, a corrupção, a improbidade e a ineficiência administrativas, sempre sob a luz dos preceitos cristãos e do respeito absoluto à dignidade da pessoa humana" ${ }^{10}$.

Rodrigo Amorim, nascido em 1978 na capital fluminense, é filiado ao Partido Social Liberal (PSL) e deputado estadual pelo Rio de Janeiro, tendo sido eleito com 140.666 votos no pleito de 2018. Possui formação em Direito e é pós-graduado em Direito do Trabalho e Legislação Social, especializado em Direito da Saúde. É membro da Mesa Permanente 
do MERCOSUL, do Conselho Americano de Desenvolvimento e integrante da Associação Fluminense de Advogados Trabalhistas.

João Luiz nasceu em 1972 no Rio de Janeiro, é apresentador, radialista e palestrante. Filiado ao Republicanos (PRB), foi eleito deputado estadual do Amazonas em 2018 com 25.858 votos. Para além de trabalhar com política, é pastor da Igreja Universal. Já presidiu a Comissão de Esporte (Comesp) da Câmara Municipal de Manaus e também foi titular da Secretaria Municipal de Juventude, Esporte e Lazer (Semjel) do município. Atualmente, é presidente da Frente Parlamentar Cristã e da Comissão de Defesa do Consumidor, ambos da Assembleia Legislativa do Estado do Amazonas (ALE-AM).

Julio César Ribeiro nasceu em 1975 em São Bernardo do Campo/ SP, possui formação em Direito e atualmente é deputado federal pelo Republicanos (PRB) de Brasília/DF, tendo sido eleito em 2018 com 79.755 votos. Foi Secretário de Esporte do Governo do Distrito Federal (GDF). É membro titular da Comissão de Esporte da Câmara dos Deputados do Brasil, onde promoveu duas audiências públicas para debater sobre transgêneros no esporte (requerimentos $n^{\circ}$ 26/2019 e $35 / 2019$ ), a primeira aos cinco dias corridos do mês de junho de 2019 e a segunda aos 26 dias corridos do mesmo mês e ano.

Sóstenes Silva Cavalcante nasceu em 1975 em Maceió/AL, possui formação em Teologia e está em seu segundo mandato na Câmara dos Deputados (o primeiro foi de 2014-2018, pelo Partido Social Democrático [PSD-RJ], e o segundo iniciado em 2019 após ser eleito em 2018 pelo Democratas [DEM] do Rio de Janeiro/RJ, com 94.203 votos). Também, é membro da Igreja Evangélica Assembleia de Deus, onde desempenha a função de pastor em uma unidade da mesma em Jacarepaguá, bairro da cidade do Rio de Janeiro. Atualmente, participa das Comissões de Educação; Cultura; Constituição e Justiça e de Cidadania; Direitos Humanos e Minorias; entre outros.

Manoel Isidório de Santana Júnior, nascido em 1962 em Salvador/ BA, é Sargento aposentado da Polícia Militar do Estado da Bahia, pastor da Assembleia de Deus e deputado federal do Partido Avante pela Bahia. Foi eleito em 2018 com 323.264 votos. Já foi por dois mandatos deputado estadual da Bahia (2011-15 e 2015-19) por outros partidos políticos, dentre eles Partido Socialista Brasileiro (PSB) entre 2011-13; Partido Social Cristão (PSC) entre 2013-15; Partido Republicano da Ordem Social (PROS) em 2016; e Partido Democrático Trabalhista (PDT), entre 2016-17. Em 2018 filiou-se ao Avante, onde permanece até hoje. Atua nas Comissões de Seguridade Social e Família; de Finanças e Tributação; de Proteção Social dos Militares; entre outros.

Para sintetizar, organizamos o quadro a seguir, que resume as informações supracitadas: 
Quadro 1

Síntese das informações dos deputados autores dos projetos

$\begin{array}{lllll}\text { Deputado } & \text { Partido } & \text { Esfera } & \text { Idade } & \text { Outras funções } \\ \text { Altair Moraes } & \text { Republicanos - PRB } & \text { Estadual - SP } & 51 & \text { Pastor } \\ \text { Rodrigo Amorim } & \text { Partido Social Liberal - PSL Estadual - RJ } & 42 & \text { Advogado } \\ \text { João Luiz } & \text { Republicanos - PRB } & \text { Estadual - AM } 48 & \text { Pastor } \\ \text { Julio César Ribeiro } & \text { Republicanos - PRB } & \text { Federal - DF } & 45 & \text { Advogado } \\ \text { Sóstenes Silva Cavalcante } & \text { Democratas - DEM } & \text { Federal - RJ } & 45 & \text { Pastor } \\ \text { Manoel Isidório de Santana Júnior } & \text { Avante } & \text { Federal - BA } & 58 & \text { Pastor }\end{array}$

Os autores

Podemos constatar que: três deputados são membros do Partido Republicanos (PRB), um partido político que compóem a direita brasileira e faz parte da base governista do atual governo presidencial de Jair Bolsonaro; um deles é membro do Partido Social Liberal (PSL) que, historicamente, esteve alinhado ao socioliberalismo, porém atualmente é mais liberal na esfera econômica, preservando, assim, costumes e tradições. Caracteriza-se como um partido conservador e foi, até 2019, o partido do atual presidente Bolsonaro (hoje sem partido); outro é membro do Democratas (DEM), partido que tem como espectro político o centro-direita à direita, apresentando caráter conservador e liberal; e outro do Avante (outrora Partido Trabalhista do Brasil-PTdoB) que, dentre esses partidos, é o único a apresentar espectro político de centro e valores alinhados ao trabalhismo, nacionalismo e humanismo cristão.

A média de idade do grupo é de 48,1, dentre os seis deputados, quatro deles desempenham funções como pastores religiosos e outros dois possuem formação em Direito, demonstrando assim conhecimento e competências para tratar de assuntos legislativos à esfera a qual são responsáveis por atuar. Pelas respectivas características, acreditamos que podemos estendê-las aos/às eleitores/as dos mesmos, portanto, é de se esperar que esses deputados estejam representando, também, o interesse do grupo de cidadãos/ãs brasileiros/as que os elegeram ao cargo em que ocupam.

\section{2- O texto de cada projeto}

Após a leitura de cada um dos projetos, constatamos redações iguais entre alguns deles, diferenciando-se apenas por um ou outro parágrafo em capítulos e/ou também pelas suas justificativas, embora também se apresentem semelhantes. Para melhor ilustrarmos esses dados, trazemos os escritos de cada um deles abaixo, onde analisamos a redação dos projetos de acordo com blocos parecidos (isto é, devido à discussão dos mesmos tópicos pelos projetos, aglutinamos nossas discussões de acordo com a similaridade dos textos apresentados):

Bloco 1- Os Projetos Estaduais 


\section{Quadro 2}

Os Projetos Estaduais

\begin{tabular}{|c|c|c|}
\hline PL & EMENTA & TEXTO \\
\hline \multirow[b]{2}{*}{$\begin{array}{c}346 / 2019^{12} \text {, } \\
\text { de Altair } \\
\text { Moraes } \\
\text { (PRB/SP) }\end{array}$} & $\begin{array}{l}\text { Estabelece o sexo } \\
\text { biológico como o } \\
\text { único critério para } \\
\text { definição do } \\
\text { gênero de } \\
\text { corrpetidores em } \\
\text { partidas } \\
\text { esportivas oficiais } \\
\text { no Estado de São } \\
\text { Paulo. }\end{array}$ & $\begin{array}{l}\text { Art. } 1^{\circ} \text { - O sexo biológico será o único critério definidor do gênero dos competidores } \\
\text { em partidas esportivas oz̃ciais no Estado de São Paulo, restando vedada a atuação de } \\
\text { transexuas em equipes cue correspondam ao sexo oposto ao de nascimento. } \\
\text { Art. } 2^{\circ} \text { - A federação, entidade ou clube de desporto que descumprir esta lei será } \\
\text { multada em até } 50 \text { (cinquenta) salários minimos. } \\
\text { Art. } 3^{\circ} \text { - Esta Lei entra em vigor } 180 \text { (cento e oitenta) dias após sua publicação. }\end{array}$ \\
\hline & $\begin{array}{l} \\
\text { Esta lei estabelece } \\
\text { estabelece a compe } \\
\dot{E} \text { notório que um } \\
\text { recebendo o titulo } \\
\text { de comunicação. } \\
\text { Tal situação vem } \\
\text { masculino, após } \\
\text { gluteoplastias de al } \\
\text { Apesar de todos o } \\
\text { fisiológico, ou seja } \\
\text { durante anos, ja as } \\
\text { jogadora de vôl } \\
\text { volei.htm\#transexu } \\
\text { Pelo fato de terem } \\
\text { Já as mulheres at1 } \\
\text { capacidade corpora } \\
\text { pegas com alto ni } \\
\text { conquistados anteri } \\
\text { Apenas como parâ } \\
\text { ng/dl, já em mulher } \\
\text { é muito grande. } \\
\text { Ademais, essa tese } \\
\text { testosterona é a cha } \\
\text { O hormônio é um } \\
\text { mulher, influencian } \\
\text { sete a oito vezes } \\
\text { testosterona e a mu } \\
\text { Para Turibio, poré } \\
\text { testosterona. Uma } \\
\text { Certamente ela se } \\
\text { adquiria um fisico. } \\
\text { não é tudo. Então, } \\
\text { negar." (https://g } \\
\text { reviravolta-do-caso } \\
\text { Portanto, pelo mé } \\
\text { beneficios, conclan }\end{array}$ & 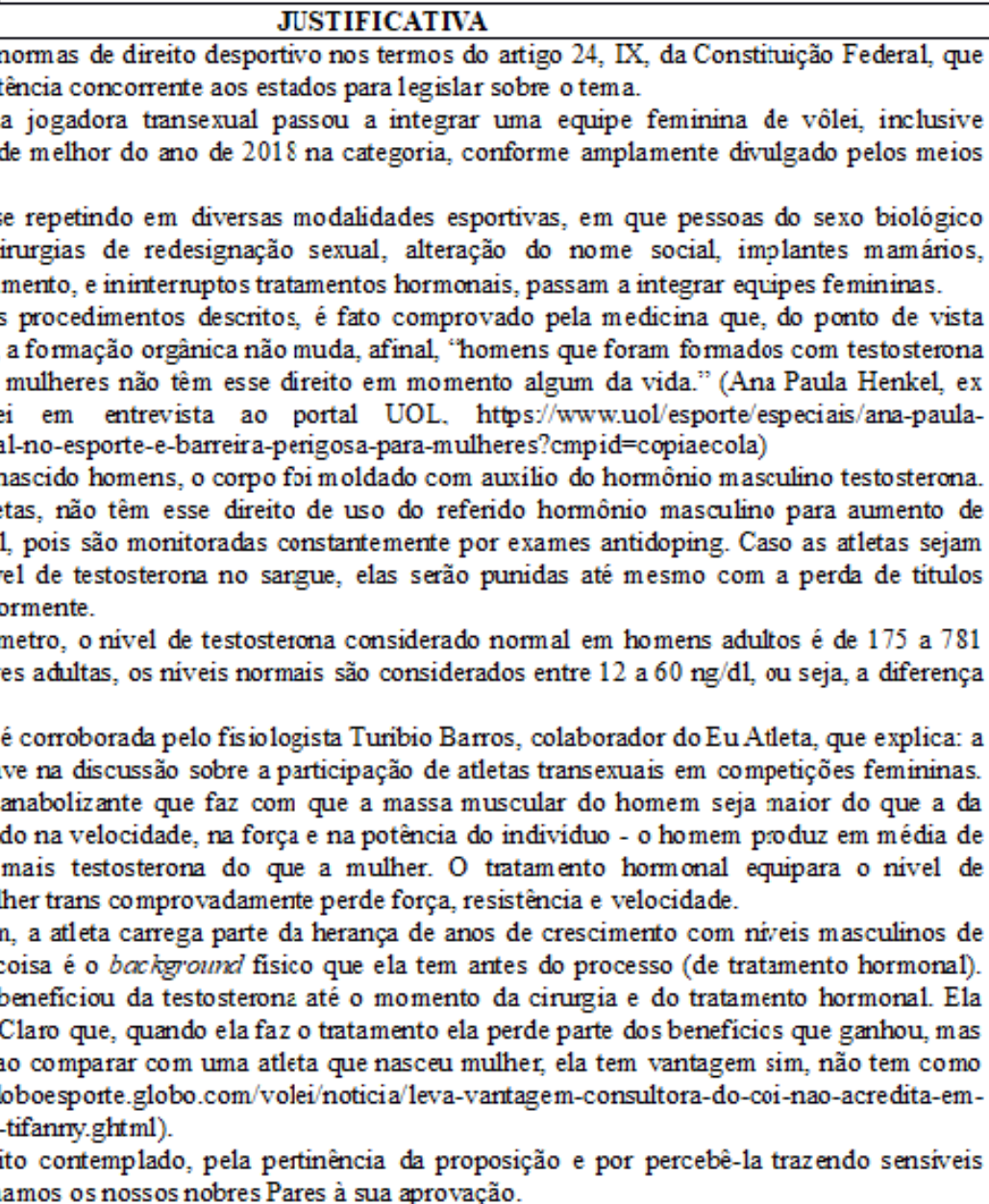 \\
\hline
\end{tabular}




\begin{tabular}{|c|c|c|}
\hline PL & EMENTA & TEXTO \\
\hline \multirow[t]{3}{*}{$\begin{array}{l}331 / 2019^{15} \\
\text { de Rodrigo } \\
\text { Amorim } \\
(\text { PSL } / \text { RJ) }\end{array}$} & $\begin{array}{l}\text { Estabelece o sexo } \\
\text { biológico como o } \\
\text { único critério para } \\
\text { definição do } \\
\text { gênero de } \\
\text { competidores em } \\
\text { partidas } \\
\text { esportivas oficiais } \\
\text { no estado do Rio } \\
\text { de Janeiro. }\end{array}$ & $\begin{array}{l}\text { Art. } 1^{\circ} \text { - Fica determinado que o sexo biológico será o único critério definidor para a } \\
\text { organização das equipes quanto ao gênero dos competidores em partidas esportivas } \\
\text { oficiais no Estado do Rio de Janeiro, sendo vedada a atuação de transgêneros em tais } \\
\text { equipes. } \\
\text { Art. } 2^{\circ} \text { - Para os fins dessa lei, transgênero é a pessoa que tem identidade de gênero, } \\
\text { ou expressão de gênero diferente de seu sexo biológico. } \\
\text { Parágrafo único- Aos transgêneros fica garantida a participação apenas em equipes } \\
\text { que correspondam ao seu sexo biológico. } \\
\text { Art. } 3^{\circ} \text { - A federação, entidade ou clube de desporto que descumprir esta lei sofreráa } \\
\text { sanção de multa de até } 50 \text { (cinquenta) salários minimos. } \\
\text { Parágrafo único- Os clubes de desporto deverão se adequar as normas da presente Lei } \\
\text { no prazo máximo de } 180 \text { (cento e oitenta) dias. } \\
\text { Art. } 4^{\circ} \text { - Esta Lei entra em vigor na data de sua publicação. }\end{array}$ \\
\hline & \multicolumn{2}{|r|}{ JUSTIFICATIVA } \\
\hline & Idêntica ao PL 346 & 2019 , com exceção do último parágrafo, que não c \\
\hline PL & EMENTA & TEXTO \\
\hline \multirow[t]{3}{*}{$\begin{array}{l}\text { 203/2019 } \\
\text { de João } \\
\text { Luiz } \\
\text { (PRB/AM) }\end{array}$} & $\begin{array}{l}\text { Estabelece o sexo } \\
\text { biológico como o } \\
\text { único critério para } \\
\text { definição do } \\
\text { gênero de } \\
\text { competidores em } \\
\text { partidas } \\
\text { esportivas } \\
\text { oficiais. }\end{array}$ & $\begin{array}{l}\text { Art. } 1^{\circ} \text { - Fica determinado que o sexo biológico será o único critério definidor do } \\
\text { gênero dos competidores em partidas esportivas oficiais no Estado do Amazonas, } \\
\text { restando vedada a atuação de transgênero em equipes que correspondam ao sexo } \\
\text { oposto ao de nascimento. } \\
\text { Parágrafo único- Para os fins desta Lei, considera-se transgênero toda pessoa que se } \\
\text { identifica com um gênero diferente daquele que corresponde ao seu sexo atribuido no } \\
\text { momento do nascimento. } \\
\text { Art. } 2^{\circ} \text { - A federação, entidade ou clube de desporto que descumprir esta lei será } \\
\text { multada em até } 50 \text { (cinquenta) salários minimos. } \\
\text { Parágrafo único- A multa será revertida para o Fundo Estadual de Esporte e Lazer - } \\
\text { FEEL, criado pela Lei Estadual n } n^{\circ} 4.279 \text {, de } 28 \text { de dezembro de } 2015 \text {. } \\
\text { Art. } 3^{\circ} \text { - O poder Executivo regulamentará esta Lei no que couber. } \\
\text { Art. } 4^{\circ} \text { - Esta Lei entra em vigor } 180 \text { (cento e oitenta) dias após sua publicação. }\end{array}$ \\
\hline & \multicolumn{2}{|r|}{ JUSTIFICATIVA } \\
\hline & \multicolumn{2}{|c|}{$\begin{array}{l}\text { Idêntica ao PL } 346 / 2019 \text {, com exceção do último parágrafo, que não consta neste documento. Consta o } \\
\text { seguinte adendo: } \\
\text { Portanto, pelo mérito contemplado, pela pertinência da proposição e por percebê-la trazendo sensiveis } \\
\text { beneficios ao esporte Amazonense, peço o apoio dos nobres pares para a aprovação da presente } \\
\text { propositura. }\end{array}$} \\
\hline
\end{tabular}

Fonte: vide notas 12, 13 e 14 .

Analisando os três projetos estaduais, podemos constatar que as ementas apresentadas possuem a mesma finalidade, sendo estabelecer como único critério para competições esportivas em seu respectivo Estado, o sexo biológico do/a atleta, e não a sua identificação de gênero aliada aos processos hormonioterapêuticos. No PL 346/2019, de Altair Moraes, não se encontra descrita a caracterização da pessoa transgênero, o que já foi incluído nos PL's 331/2019 de Rodrigo Amorim e 203/2019 de João Luiz, porém de maneira superficial.

Jesus (2012) promove uma reflexão sobre o que é ser uma pessoa trans a partir de um guia didático de conceitos. Primeiro, a autora destaca que, em termos de gênero, todas as pessoas podem ser enquadradas como trans ou cis. As pessoas cis são aqueles que se identificam no gênero que lhes foi atribuído no nascimento, já as pessoas trans são aquelas que se desidentificam com essa imputação social.

Ainda conforme Jesus (2012), é importante destacar que não existe um consenso sobre o termo trans no Brasil. "Há quem se considere transgênero, como uma categoria à parte das pessoas travestis e transexuais. Existem ainda as pessoas que não se identificam com qualquer gênero, não há consenso quanto a como denominá-las" (Jesus, 2012, p. 10). A autora complementa dizendo que o termo queer pode ser utilizado, também, para designar pessoas trans, ou também a terminologia 
"andrógino", já que ambos podem, em escalas próximas, representar incontingências da fixação do gênero.

Nesse sentido, Le Breton (2014) demarca a diferenciação entre os conceitos de transexualidade e transgeneridade que, embora possam ser aglutinados em um círculo comum - juntamente das travestis - na expressão de pessoas trans, difere-se no sentido de que o primeiro adota para si e alicerça uma posição do sexo/gênero, enquanto que o segundo recusa essas posições, principalmente aquelas de ordem binária, e deflagrase como problematizadora das diferenças.

Le Breton (2014, p. 24) afirma que "A movência transgênero traduz, inversamente, a recusa dos binarismos [...] e anuncia a vontade de problematizar as diferenças, de multiplicá-las ao invés de organizá-las e categorias instáveis". E assim, continua: “[...] ir além [...] numa espécie de recusa da dualidade dos sexos [...] se tornando incatalogável” (p. 25).

Em consonância, Jesus (2012, p. 10) sinaliza dois aspectos importantes para reconhecer a diversidade de formas possíveis de se viver o gênero na dimensão denominada de "trans": "1. Identidade (o que caracteriza transexuais e travestis); OU como 2. Funcionalidade (representado por crossdressers, drag queens, drag kings e transformistas)". Neste panorama, Jesus (2012) propõe a noção de "transgener(al)idades", alertando para que fujamos dos estereótipos identificadores de uma noção trans, já que uma pessoa transgênero, assim como qualquer outra pessoa, vivencia inúmeros outros aspectos de sua humanidade para além daquelas concernentes ao seu gênero, representando uma multiplicidade de identificações a partir de “[...] diferentes cores, etnias, classes, origens geográficas, religiões, idades, orientações sexuais, uma rica história de vida, entre outras características" (p. 12).

Portanto, torna-se importante compreender as transgeneralidades para além de uma desidentificação com o gênero ou sexo atribuídos no nascimento, já que o recorte histórico sobre esta população, como bem escreve Jesus (2012), denuncia aspectos de estigmatização, marginalização e perseguição social devido a uma crença de anormalidade àquilo que se estabeleceu como natural, ou também normal, entre o sexo de nascimento, a orientação sexual e a identidade de gênero da pessoa humana. Esse conjunto de violações compõem um conjunto de crimes físicos ou simbólicos de ódio que são motivados pelo preconceito à identificação não-cis, sendo esse fenômeno reconhecido como transfobia, isto é, ações de preconceito e discriminação que são direcionadas às pessoas transgênero em função de sua identificação e expressão de gênero (Jesus, 2012).

Continuando nossa análise, destaca-se a punição para cada Federação, entidade ou clube esportivo que descumprir as medidas dos PL's, a mesma nos três projetos ( 50 salários mínimos), bem como o tempo de adequação e/ou para a lei entrar em total vigor (180 dias). A justificativa dos projetos é idêntica, exceto pelo parágrafo final de cada uma delas, que discorre sobre a implementação do PL em seu respectivo Estado. Entretanto, a fundamentação da redação é frágil em termos científicos, pois traz à tona como consenso afirmações sem dados e/ou embasamentos concretos e 
de pessoas que não são especialistas nas temáticas narradas. Analisaremos melhor os trechos nos parágrafos que se seguem.

A primeira sentença afirma estar amparada pelo artigo 24, inciso IX, da Constituição Federal (CF) de $1988^{15}$, que estabelece a competência concorrente aos Estados para legislar sobre educação, cultura, ensino, desporto, ciência, tecnologia, pesquisa, desenvolvimento e inovação (Redação dada pela Emenda Constitucional no 85, de 2015). Porém, cabe frisar que na mesma CF, em seu artigo 217, explicita-se o dever do Estado de fomentar práticas desportivas formais e não formais como direito de todos/as, observado em seu inciso I que as entidades esportivas e seus dirigentes possuem autonomia para gerir e organizar as práticas sob sua competência. Atualmente, o Comitê Olímpico Brasileiro (COB) e as Confederações Nacionais, no exercício de sua autonomia, seguem as recomendações do COI sobre a política de verificação e participação de atletas trans em competições brasileiras.

No segundo parágrafo, traz-se à tona o caso de Tifanny, afirmando que "uma jogadora transexual passou a integrar uma equipe feminina de vôlei, inclusive recebendo o título de melhor do ano de 2018 na categoria, conforme amplamente divulgado pelos meios de comunicação". Neste discurso, não fica claro ao leitor que Tifanny foi eleita a melhor jogadora apenas do campeonato paulista de voleibol de 2018, sugerindo que a mesma possa ter sido a melhor jogadora nacional da modalidade, quando não o foi.

Logo em seguida, afirma-se que essa "situação vem se repetindo em diversas modalidades esportivas", dando ênfase às pessoas que transicionam o gênero de homem para mulher e passam a integrar equipes femininas. Porém, a redação não explicita quais são esses casos, abrindo margem para um alarde falacioso de que muitas atletas mulheres trans estariam ocupando inúmeros espaços esportivos, além de sugerir que esta participação excluiria, inegavelmente, a ocupação por mulheres cisgênero do esporte - o que, até o presente momento, não foi constatado.

Embora o texto cite os procedimentos que são realizados pelas atletas mulheres trans para se readequarem ao gênero de identificação e às normas das Confederações para poderem participar das competições femininas de suas modalidades, afirma que já se está comprovado cientificamente pela medicina que todas as alterações promovidas no aparato morfofisiológico não se alteram completamente, trazendo como referência o discurso de Ana Paula, que não é médica ou fisiologista, mas sim uma ex-atleta de voleibol que demonstra forte conflito de interesse na temática. Vale lembrar que, até hoje, ainda não há consenso científico se atletas trans apresentam desempenho melhor que atletas cis em função do sexo biológico e dos efeitos da hormonização (Camporesi, 2019).

Outro ponto que se pode notar é a imprecisão do trato com as conceituações de gênero, sexo e sexualidades. Os deputados autores afirmam que os atletas "nascem homens", negando e/ou não reconhecendo os fatores sociais que constroem e moldam os corpos à luz das relações de gênero, juntamente dos fatores biológicos e do meio ao qual estão inseridos. Ignorar ou não se atentar para esses fatores torna- 
se caro ao discurso proposto, pois corrobora para a invalidade desta argumentação, além de estimular a desorientação pela temática debatida.

Posteriormente, fazem uma comparação entre os níveis de testosterona entre homens e mulheres cis, desconsiderando a identificação da mulher trans, além de não evidenciaram de forma elucidativa todos os processos fisiológicos que a terapia hormonal $(\mathrm{TH})$ acarreta em seus corpos promovendo alterações significativas na redistribuição da gordura corporal e diminuição da massa muscular/força já nos primeiros três meses de tratamento (World Professional Association for Transgender Health, 2012).

Ao acionarem o fisiologista Turíbio Barros, profissional que dentre todos/as os/as mobilizados/as enquanto referenciais é o que apresenta mais propriedade teórico-conceitual e científico para tratar sobre aspectos biofisiológicos humanos, atêm-se ao discurso da testosterona enquanto único fator primordial para a divisão dos esportes em masculino e feminino, reduzindo-a a apenas este hormônio como peça-chave para a equidade e justiça das competições esportivas, o que é problematizado por Karkazis, Jordan-Young, Davis y Camporesi (2012) e Karkazis y Carpenter (2018). Nesta oportunidade, esses/as autores/as sinalizam que existem outras condições tão ou até mesmo mais importantes que os hormônios androgênicos que influenciam no desempenho esportivo, tais como variações mitocondriais; disfunções crônicas que ocasionarão mudanças consideráveis na estrutura morfofisiológica, como acromegalia e síndrome de Marfan, por exemplo; mutações genéticas que alterarão a eficiência muscular ou o aporte sanguíneo para os músculos esqueléticos, por exemplo; os diferentes níveis de acuidade visual; dentre outros, sendo um desacerto fixar-se apenas à testosterona como parâmetro de decisão para fragmentar as competições em masculino e feminino (Karkazis et al., 2012; Karkazis y Carpenter, 2018), o que chega a ser, inclusive, uma crítica às próprias recomendações do COI.

$\mathrm{O}$ argumento apresentado pelos projetos que mais apresenta robustez científica "é o background físico que ela [mulher trans] tem antes do processo (de tratamento hormonal). Certamente ela se beneficiou da testosterona até o momento da cirurgia e do tratamento hormonal". Essa consideração, entretanto, deve ser aprofundada e investigada de maneira mais terminante, pois até o presente, ainda é uma ideia controversa e não totalmente comprovada pela ciência, sendo, portanto, apenas um indício especulativo profícuo (Sőnksen et al., 2018; Camporesi, 2019; Devine, 2019).

Por fim, no depoimento de Turíbio, o fisiologista afirma que "ao comparar com uma atleta que nasceu mulher, ela [mulher trans] tem vantagem sim, não tem como negar". Essa conclusão chega a ser problemática, pois, assim como os deputados autores, desconsidera os processos socioculturais que fazem de um corpo tornar-se mulher, além de afirmar precipitadamente que existe uma vantagem biológica, quando ainda existem muitas dúvidas no meio científico para se estabelecer o que é uma vantagem ou não no campo esportivo (Karkazis y Carpenter, 2018; 
Betancurt, Zakynthinaki, Martinez-Patiño y Martinez, 2018; Anderson, Knox y Heather, 2019).

Todos os argumentos apresentados na redação da justificativa dos projetos estaduais são, portanto, frágeis em termos de fundamentação teórico-científica, utilizando-se de saberes consolidados no senso comum e que são expandidos como afirmação já consolidada cientificamente, o que vai na contramão do cenário de pesquisas que envolvem as práticas esportivas por pessoas trans. Assim sendo, é possível identificar certo caráter transfóbico, ainda que velado, que tenta acionar e validar discursos biofisiológicos com base em saberes do corpo cis para justificar a não participação de atletas mulheres trans em competições femininas, vedando-as à participação vexatória, humilhante e desigual entre homens cisgênero à luz das ordenações dos sexos biológicos (Devine, 2019).

Bloco 2- Os Projetos Federais

\section{Quadro 3}

Os Projetos Federais

\begin{tabular}{|c|c|c|}
\hline PL & EMENTA & TEXTO \\
\hline \multirow{3}{*}{$\begin{array}{c}2596 / 201 \\
9^{16} \text {, de Julio } \\
\text { César } \\
\text { Ribeiro } \\
\text { (PRB/DF) }\end{array}$} & $\begin{array}{l}\text { Estabelece o sexo } \\
\text { biológico como } \\
\text { único critério para } \\
\text { definição do } \\
\text { gênero em } \\
\text { competições } \\
\text { esportivas oficiais } \\
\text { no território } \\
\text { brasileiro. }\end{array}$ & $\begin{array}{l}\text { O Congresso Nacional decreta: } \\
\text { Art. } 1^{\circ} \text { - O sexo biológico é o único critério definidor do gênero dos competidores } \\
\text { em competições esportivas em todo o território nacional, sendo vedada a atuação de } \\
\text { trans gêneros em equipes do sexo oposto ao do nascimento. } \\
\text { Art. } 2^{\circ} \text { - As entidades de administração do desporto e as entidades de prática } \\
\text { desportiva que não observarem esta lei, na oportunidade da inscrição de seus atletas } \\
\text { em competições oficiais, serão desclassificadas e/ou multadas, conforme } \\
\text { regulamento. } \\
\text { Parágrafo único- comprovado o desconhecimento dos responsáveis pela inscrição da } \\
\text { condição do atleta transgênero, ainda que a equipe beneficiada tenha sido premiada, o } \\
\text { prêmio ou o titulo será anulado automaticam ente, sem prejuizo da apuração de } \\
\text { responsabilidades. } \\
\text { Art. } 3^{\circ} \text { - O atleta transgênero que omitir sua condição da respectiva entidade de } \\
\text { administração do desporto e da respectiva entidade de prática desportiva, responderá } \\
\text { por doping e será banido do esporte. } \\
\text { Art. } 4^{\circ} \text {-Esta lei entra em vigor na data da sua publicação. }\end{array}$ \\
\hline & & JUSTIFICAC̣Á \\
\hline & \multicolumn{2}{|c|}{$\begin{array}{l}\text { A participação de atletas transgêneros em competições esportivas oficiais vem se repetindo em diversas } \\
\text { modalidades em todos as unidades da Federação brasileira. Embora seja de conhecimento geral que, para } \\
\text { a transformação de sexo, faz-se necessário o uso de hormônios e de cinurgias invasivas de grande } \\
\text { complexidade, já ficou comprovado pela medicina, que a formação fisiológica do atleta transgênero não } \\
\text { se altera, o que representa, portanto, vantagem desses atletas em relação aos demais. } \\
\text { Em casos em que a mudança de sexo só ocorre em estágio de vida mais avançado, quando a musculatura } \\
\text { e composição óssea já estão mais formadas, sua formação fisiológica continua masculina, sendo desigual } \\
\text { a sua condição fisica em relação às demais atletas. } \\
\text { A proposta em exame, sem nenhuma intenção preconceituosa contra os trans gêneros, visa apenas a } \\
\text { assegurar a igualdade entre forças entre as equịes que disputam titulos em todo o território nacional. } \\
\text { Os niveis de testosterona entre homens e mulheres, hormônio que influencia diretamente na condição } \\
\text { fisica e força do ser humano, é extremamente desigual. Enquanto o homem apresenta niveis de } \\
\text { testosterona entre } 175 \text { e } 781 \mathrm{ng} \text { dl, as mulheres estão limitadas entre } 12 \text { e } 60 \text {, isto é, a desigualdade é } \\
\text { extremamente relevante. } \\
\text { Reforçamos que a intenção da proposta não é a de promover preconceito, mais a de igualar as condições } \\
\text { entre competidores. Contamos com o apoio dos nobres pares na aprovação do presente projeto. }\end{array}$} \\
\hline
\end{tabular}




\begin{tabular}{|c|c|c|}
\hline PL & EMENTA & TEXTO \\
\hline \multirow[b]{3}{*}{$\begin{array}{l}2639 / 201 \\
9^{17} \text {, de } \\
\text { Sóstenes } \\
\text { Silva } \\
\text { Cavalcante } \\
\text { (DEM/RJ) }\end{array}$} & $\begin{array}{l}\text { Estabelece o sexo } \\
\text { biológico como } \\
\text { critério exclusivo } \\
\text { para a definição } \\
\text { do gênero em } \\
\text { competições } \\
\text { esportivas ofíciais } \\
\text { no Brasil. }\end{array}$ & $\begin{array}{l}\text { O Congresso Nacional decreta: } \\
\text { Art. } 1^{\circ} \text { - O sexo biológico será o critério exclusivo para definir o gênero dos atletas } \\
\text { em competições esportivas profissionais no Brasil. } \\
\text { Art. } 2^{\circ} \text { - As entidades de administração do desporto deverão averiguar o disposto } \\
\text { nesta Lei, na ocasião das inscrições de atletas em suas respectivas competições. } \\
\text { Parágrafo único- Em caso de inobservância do caput deste artigo, as entidades de } \\
\text { administração do desporto serão multadas, conforme regulam ento. } \\
\text { Art. } 3^{\circ} \text { - Esta lei entra em vigor na data da sua publicação. }\end{array}$ \\
\hline & \multicolumn{2}{|c|}{ JUSTIFICAC̣ÃO } \\
\hline & \multicolumn{2}{|c|}{$\begin{array}{l}\text { Este Projeto de Lei visa a defender o principio da justiça nas competições esportivas profissionais } \\
\text { realizadas em território brasileiro. } \\
\text { A participação de atletas do sexo masculino que, após cirurgias de redesignação sexual e/ou tratamentos } \\
\text { hormonais, passam a integrar equipes femininas, realidade presente em algumas modalidades esportiva do } \\
\text { pais, causa evidentes desequilibrios técnicos e coloca em risco a própria lisura das competições. } \\
\text { Isso ocorre, pois, mesmo o controle dos niveis de testosterona sanguinea abaixo de } 10 \text { nmol/L, de ao } \\
\text { menos } 12 \text { meses anteriores à disputa de um tomeio, condição do Comitê Olimpico Internacional (COI) } \\
\text { para aceitação de mulheres transgêneros no esporte, não altera significativamente a musculatura e a } \\
\text { estrutura óssea, própria do sexo masculino, especialmente em atletas com composição corporal já } \\
\text { completa. } \\
\text { Assim, do ponto de vista físiológico, esses atletas vêm apresentando injustas vantagens comparativas. } \\
\text { Trata-se, portanto, de proposição que visa a promover o equilibrio no esporte masculino e feminino, sem } \\
\text { qualquer tịo de juizo de valor acerca das opções da vida privada de homens e mulheres. } \\
\text { Contamos com o apoio dos nobres pares na approvação do presente projeto. }\end{array}$} \\
\hline PL & EMENTA & \\
\hline $\begin{array}{l}2200 / 201 \\
9^{18}, \text { de } \\
\text { Manoel } \\
\text { Is idório de } \\
\text { Santana } \\
\text { Júnior } \\
\text { (AVANTE/ } \\
\text { BA) }\end{array}$ & 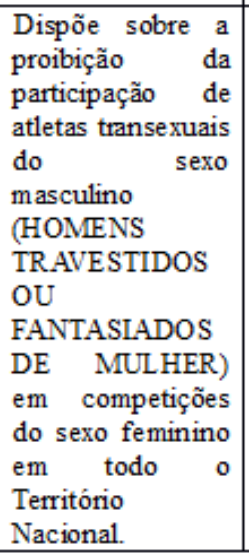 & $\begin{array}{l}\text { O Congresso Nacional decreta: } \\
\text { Art. } 1^{\circ} \text { - Fica vedada a participação de atletas transexuais do sexo masculino em } \\
\text { competições do sexo feminino em modalidades esportivas no Território Nacional, } \\
\text { estabelecendo o sexo biológico como único critério para definição do gênero de } \\
\text { competidores em partidas esportivas oficiais na Nação Brasileira. } \\
\text { Parágrafo único- Fica permitido aos transexuais criarem competições entre si, desde } \\
\text { que sejam entre os mesmos sexos biológicos, sendo homens transexuais com homens } \\
\text { transexuais e mulheres transexuais com mulheres transexuais. } \\
\text { Art. } 2^{\circ} \text { - Esta lei entra em vigor na data de sua publicação. }\end{array}$ \\
\hline
\end{tabular}




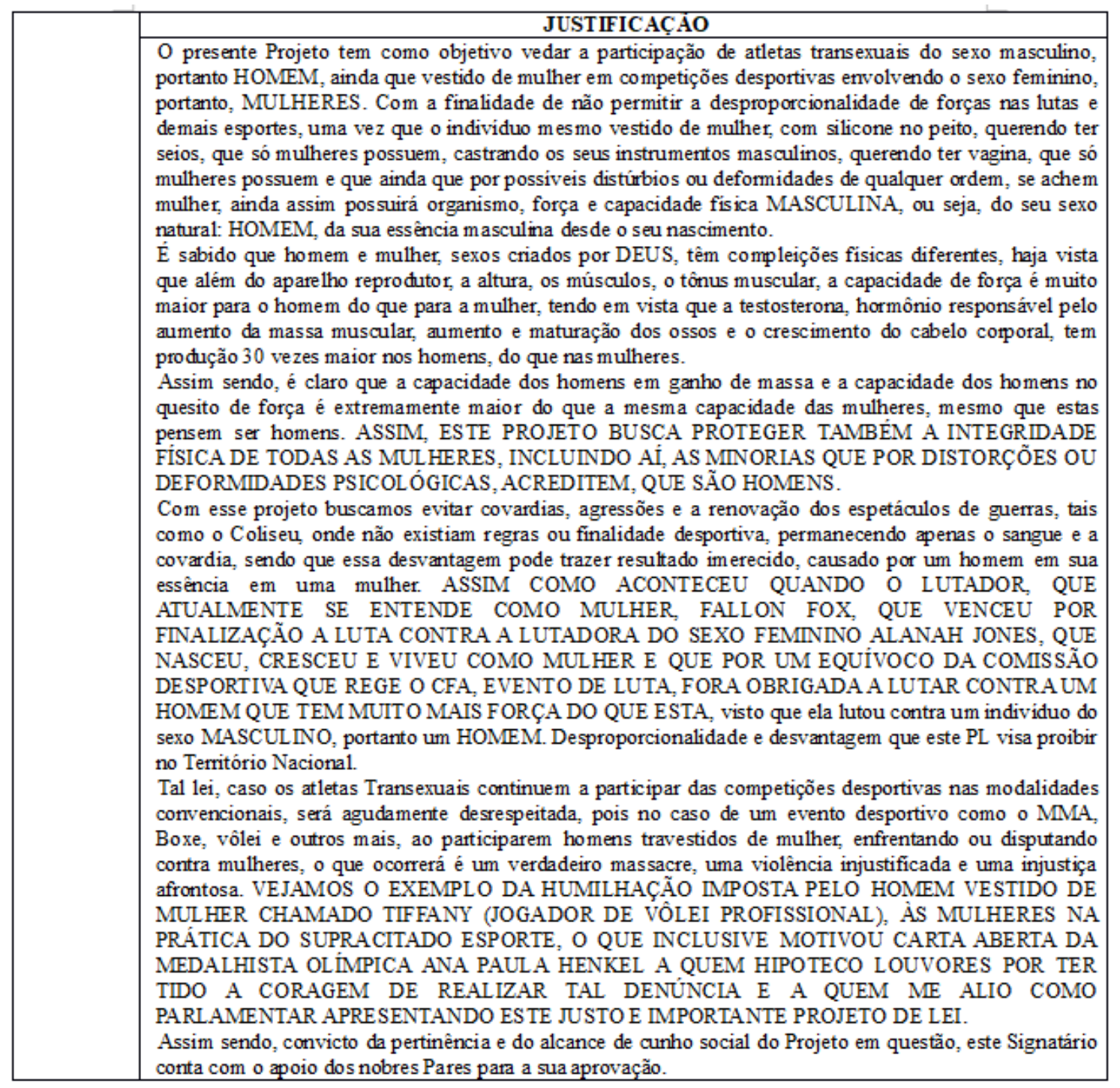

Fonte: vide notas 16,17 e 18 .

Assim como os projetos estaduais, os projetos federais apresentam como ementa utilizar-se do sexo biológico como único parâmetro para as competições esportivas no país. Os PL 2596/2019 e PL 2639/2019 apresentam em suas justificações, respectivamente, que a presença de atletas trans em eventos esportivos estão presentes em todas as federações brasileiras, e crescendo exponencialmente pelo Brasil. Esta afirmação chega ser incerta, uma vez que dos 26 Estados, mais o Distrito Federal, a única atleta trans no alto rendimento é Tifanny Abreu, em São Paulo, e em competições não profissionais temos casos isolados nos estados da Bahia, São Paulo e Paraná, apenas ${ }^{19}$. Logo, seria importante que nos projetos viessem explicitados todos os casos, além de especificá-los um a um para que pudessem ser averiguados, evitando assim uma generalização especulativa que, pelo tecido discurso, soa como verdade impetrável.

Também, as redações se sustentam nas afirmações de que as remodelações promovidas pela terapia hormonal não são suficientes para readequar o corpo da mulher trans, especificamente, para competir com as mulheres cis. Afirmam que "Embora seja de conhecimento geral que, 
para a transformação de sexo, faz-se necessário o uso de hormônios e de cirurgias invasivas de grande complexidade, já ficou comprovado pela medicina, que a formação fisiológica do atleta transgênero não se altera, o que representa, portanto, vantagem desses atletas em relação aos demais" (PL 2596/2019) e que "[...] o controle dos níveis de testosterona sanguínea abaixo de $10 \mathrm{nmol} / \mathrm{L}$, de ao menos 12 meses anteriores à disputa de um torneio, condição do Comitê Olímpico Internacional (COI) para aceitação de mulheres transgêneros no esporte, não altera significativamente a musculatura e a estrutura óssea, própria do sexo masculino, especialmente em atletas com composição corporal já completa. Assim, do ponto de vista fisiológico, esses atletas vêm apresentando injustas vantagens comparativas" (PL 2639/2019). Assim como os projetos estaduais, os federais também afirmam que a medicina já comprovou a vantagem fisiológica da atleta trans frente a atleta cis, e que as características morfofisiológicas da primeira não sofrem tamanho impacto a ponto de permitir sua elegibilidade junto da segunda, reforçando apressadamente discursos que não podem ser fixados atualmente. Em contra-argumentação, trazemos os dados abaixo para analisar as ilações apresentadas nos projetos que, embora tomadas como consolidadas cientificamente, não citaram aporte científico-bibliográfico algum.

Wiik et al. (2019) analisaram os efeitos da terapia hormonal cruzada para transgêneros na força muscular isocinética dos extensores e flexores do joelho e o volume e tamanho/composição muscular dos membros inferiores de onze mulheres trans $(\mathrm{MtF})$ e doze homens trans ( $\mathrm{FtM})$, durante um ano, com avaliações antes, durante e após a TH.

Como resultados, os/as autores/as encontraram, em FtM, aumento da força, aumento do volume muscular da coxa em 15\%, aumento de $15 \%$ da área transversal do quadríceps e aumento da densidade radiológica de $6 \%$. Em $\mathrm{MtF}$, os níveis de força se mantiveram ou aumentaram insignificativamente, e os demais parâmetros diminuíram, correspondentemente, em -5\% (volume muscular) e $-4 \%$ (área transversal), enquanto a densidade radiológica se manteve. Eles/as concluíram que a $\mathrm{TH}$ afetou acentuadamente a força, tamanho e composição muscular em pessoas trans, porém as $\mathrm{MtF}$ permanecem mais fortes e têm mais massa muscular após 12 meses de tratamento se comparado aos $\mathrm{FtM}$, o que fornece subsídios importantes para se avaliar a elegibilidade das mulheres trans em competir nas categorias femininas de competições atléticas (Wiik et al., 2019).

Em estudo de Wilson et al. (2019), os/as autores/as desenvolveram um estudo de caso com uma corredora trans de 28 anos que realizou tratamento hormonal com estrogênio, objetivando avaliar de forma abrangente os fenótipos cardiovasculares antes e durante o tratamento. Para tanto, realizaram duas avaliaçóes de base, uma antes do início do tratamento hormonal e outra logo após. Os testes após o início do tratamento com estrogênio foram realizados em intervalos de 4-8 semanas, incluindo ecocardiografia em repouso para avaliação da função biventricular do coração, absorciometria de dupla energia por raios-X 
(DEXA) para medição da densidade mineral óssea, aferição da pressão arterial central e avaliação da rigidez. O pico de volume de oxigênio (VO2) baseado na esteira e a economia de corrida, bem como o débito cardíaco não invasivo e a diferença de $\mathrm{VO} 2$ em repouso e no pico do exercício também foram quantificados em cada consulta.

Os/as autores/as encontraram, durante os primeiros 12 meses de tratamento, uma queda no volume sistólico de 136 para $80 \mathrm{ml} /$ batida do coração, com uma redução inicial no pico da frequência cardíaca variando de 188 a $180 \mathrm{bpm}$. Em consequência, o pico do débito cardíaco diminuiu de $28,4 \mathrm{~L} / \mathrm{min}$ para $15,5 \mathrm{~L} / \mathrm{min}$, enquanto que a diferença de VO2 aumentou de 11,6 para 19,9 $\mathrm{ml} \mathrm{de} \mathrm{O2/100} \mathrm{ml}$ de sangue.

Isso resultou na redução do pico absoluto de $\mathrm{VO} 2$ de 3,3 para $3,1 \mathrm{~L} /$ min. A fração de ejeção diminuiu de $61 \%$ para $57 \%$, juntamente com a diastologia do ventrículo esquerdo (válvula mitral E/e de 6.0 para 4.1). A alteração da área fracionária do ventrículo direito não foi afetada, permanecendo em 53\%, enquanto que as medidas da diastologia do coração direito aumentaram (válvula tricúspide E/e de 3.9 para 4.6). A tensão ventricular, tanto no ventrículo direito (VD) quanto no esquerdo (VE), melhorou inicialmente com a adição de estrogênio, posteriormente piorando no decorrer da TH (a tensão no VD variou de -36 a $-31,5 \%$, e de $-23,5$ a $-19 \%$ no VE).

Em conclusão, os/as autores/as apontam que a administração terapêutica de estrogênio e o bloqueio da testosterona podem afetar adversamente a aptidão cardiopulmonar através da redução do desempenho do miocárdio no pico do exercício, podendo estar associado com a piora da tensão do VE e do VD em repouso. Como sugestão, recomendam mais pesquisas para examinar os efeitos a longo prazo da $\mathrm{TH}$ na função cardiovascular de MtF.

A World Professional Association for Transgender Health (2012) argumenta que as mudanças corporais oriundas da hormonização em sujeitos trans ocorrem, em maioria, no intercurso de dois anos, podendo variar ou não. Tais mudanças encontram-se descritas abaixo (trazemos apenas os dados referentes aos hormônios feminizantes, já que os projetos se limitam a discutir apenas sobre a participação de mulheres trans): 


\section{Quadro 4}

Efeitos e tempo esperado dos hormônios feminizantes a

\begin{tabular}{|c|c|c|}
\hline Ef eito & $\begin{array}{c}\text { Início } \\
\text { esperado }{ }^{b}\end{array}$ & $\begin{array}{l}\text { Máximo efeito } \\
\text { esperado b }\end{array}$ \\
\hline Redistribuição da gordura corporal & 3-6 meses & $2-5$ anos \\
\hline Diminuição da massa muscular/força & $3-6$ meses & $1-2 \operatorname{anos}^{c}$ \\
\hline Suavização da pele / diminuição da oleosidade & 3-6 meses & desconhecido \\
\hline Diminuição da libido & $1-3$ meses & $1-2$ anos \\
\hline Diminuição de ereções espontâneas & $1-3$ meses & $3-6$ meses \\
\hline Disfunção sexual masculina & variável & variável \\
\hline Crescimento mamário & $3-6$ meses & $2-3$ anos \\
\hline Diminuição do vohume testicular & 3-6 meses & $2-3$ anos \\
\hline Diminuição da produção de esperma & variável & variável \\
\hline $\begin{array}{l}\text { Perda e crescimento desacelerado do pelo corporal ou } \\
\text { facial }\end{array}$ & $6-12$ meses & $>3$ anos $^{d}$ \\
\hline Calvicie de padrão masculino & $\begin{array}{c}\text { Sem rebrote, } \\
\text { perda se detém 1- } \\
3 \text { meses }\end{array}$ & $1-2$ anos \\
\hline \multicolumn{3}{|c|}{$\begin{array}{l}\text { a - Adaptado com a autorização de Hembree et al. (2009). Copyright } 2009 \text {. Sociedade de Endocrinologia. } \\
\text { b-As estimações representam observações clinicas publicadas e não publicadas. } \\
\text { c-Altamente dependente da idade e hereditariedade; pode ser minimo. } \\
\text { d-Dependem significativamente da quantidade de exercicio. }\end{array}$} \\
\hline
\end{tabular}

World Professional Association for Transgender Health (2012)

Tais mudanças vêm, inclusive, acompanhadas de riscos fisiológicos desencadeados pela automedicação, dose, via de administração e características clinico-individuais de cada usuária, podendo ser dividido em três categorias: "(i) provável aumento de risco com a terapia hormonal, (ii) possível aumento de risco com a terapia hormonal, ou (iii) aumento de risco questionável ou não documentado" (World Professional Association for Transgender Health, 2012, p. 44). Abaixo, encontram-se descritos os riscos associados à terapia hormonal feminizante ${ }^{20}$ : 


\section{Quadro 5}

Riscos associados à terapia hormonal feminizante

\begin{tabular}{|c|c|}
\hline Nível de risco & Hormônios feminizantes \\
\hline \multirow{5}{*}{ Provável aumento de risco } & Doença tromboembólica venosa \\
\hline & Cálculos biliares \\
\hline & Enzimas hepáticas elevadas \\
\hline & Aumento de peso \\
\hline & Hipertrigliceridemia \\
\hline \multirow{2}{*}{ Provável aumento de risco na presença de fatores de risco adicionais $\mid$} & Doença cardiovascular \\
\hline & Diabetes tipo $2^{a}$ \\
\hline \multirow[b]{2}{*}{ Possivel aumento de risco } & Hipertensão \\
\hline & $\begin{array}{l}\text { Hiperprolactinemia ou } \\
\text { prolactinoma }\end{array}$ \\
\hline $\begin{array}{l}\text { Sem aumento de risco ou evidência de risco não concluinte ou não } \\
\text { documentada }\end{array}$ & Câncer de mama \\
\hline \multicolumn{2}{|c|}{$\begin{array}{l}\text { a - O risco é maior com a administração de estrogênios orais que com a administração de estrogênios } \\
\text { trans dérmicos. } \\
\text { b-Outros fatores de risco incluem a idade. } \\
\text { c-Incluem transtorno bipolar, esquizoafetivo e outros que podem incluir sintomas maniacos ou psicóticos. } \\
\text { Este evento adverso parece estar associado a doses mais altas ou concentrações suprafis iológicas da } \\
\text { testosterona no sangue. }\end{array}$} \\
\hline
\end{tabular}

- Itens em negrito são clinicamente significativos

World Professional Association for Transgender Health (2012)

Estes dados, pelo que se observa nos projetos, não são considerados, uma vez que não encontramos indicativos de discussão sobre as condições socioemocionais e/ou de saúde de pessoas trans. Como consta inclusive nos PL's 2596/2019 e 2639/2019, o caráter dos mesmos não seria reforçar preconceitos ou discriminações, porém podemos perceber certa negação legislativa em se atentar para as reais necessidades da população trans, o que soa, no mínimo, contraditório segundo as intenções das propostas.

Por fim, dentre todos os projetos, destaca-se negativamente pelo uso de linguagem simbolicamente violenta o de número 2200/2019, do deputado Manoel Isidório. $\mathrm{O}$ autor propõe que transexuais criem competições exclusivas, o que, além de ser um elemento excludente e contrário à Constituição Federal de 1988 com base em preceitos dos Diretos Humanos (já que segrega e distingue pessoas cisgêneras e trans) reforça as premissas de exclusão, injustiça e desvalia das relações de gênero e sexualidade no esporte moderno.

Um equívoco na ementa e no discorrer do presente texto é a ideia de que mulheres trans são homens travestidos de mulheres, que assim se caracterizam apenas para garantirem vantagens atléticas sobre seus pares cisgêneros. Nesse primeiro momento, convém ressaltar que a redação está se tratando de travestis, e não de mulheres trans, que não seguem as 
recomendações do COI de 2015. Também, pelo enunciado construído, desvirtua-se a trajetória de identificação/vida de toda /qualquer pessoa que se sinta e/ou reconheça mulher trans e que recorre a meios estéticos e medicinais para construir essa identificação, o que corrompe seus verdadeiros anseios ao sugerir que toda pessoa trans no esporte está trapaceando e agindo de maneira contrária aos princípios esportivos, ferindo, assim, sua moral e dignidade enquanto pessoa humana (o que chega a ser uma violação constitucional dos direitos humanos dessa pessoa).

Outro ponto da redação que se destaca é o acionamento discursivo bíblico para explicar as diferenças fisiológicas entre homens e mulheres, fixando o gênero ao sexo e vice-versa, afirmando que toda e qualquer mudança anatômica promovida nos corpos de pessoas trans faz parte de uma trapaça não apenas individual, mas também religiosa, o que mais uma vez vai na contramão dos direitos previstos pela CF (vide nota 15 ), se nos atentarmos ao art. $5^{\circ}$, que diz: "Todos são iguais perante a lei, sem distinção de qualquer natureza, garantindo-se [...] a inviolabilidade do direito à vida, à liberdade, à igualdade, à segurança e à propriedade" (s/p).

Por ser constitucionalmente um Estado Laico, é garantido pelo art. $5^{\circ}$, inciso VI, a livre prática religiosa da população, sendo, portanto, de bom alvitre, que os projetos apresentados não se constituam em função de qualquer crença religiosa. Também, vale-se atentar para o art. $3^{\circ} \mathrm{da} \mathrm{CF}$, incisos I, III e IV, que almejam, respetivamente, "Construir uma sociedade livre, justa e solidária" (s/p); "[...] reduzir as desigualdades sociais e regionais" ( $\mathrm{s} / \mathrm{p}$ ) e "Promover o bem de todos, sem preconceitos de origem, raça, sexo, cor, idade e quaisquer outra formas de discriminação" (s/p).

Logo, o projeto deveria: 1- repensar sobre o livre direito das pessoas trans em se inserirem e participarem das competições esportivas desde que sigam os parâmetros já elaborados internacionalmente; 2- evitar a marginalização das pessoas trans e a suspeição de sua índole e reputação enquanto pessoa humana através da sujeição de trapaça pela travestilidade e; 3- considerar o direito ao reconhecimento de gênero da pessoa trans , amparado pelas recomendações do Comitê Olímpico Internacional e dos Direitos Humanos, ambas universais.

Também no discurso deste PL, é possível identificar certos traços de transfobia ao sugerir-se a manifestação de uma "distorção ou desordem psicológica” em pessoas trans que as fazem se identificar no gênero oposto, o que corrobora para a cristalização da patológica condição de "transexualismo", termo já em desuso e retirado do CID-11 21 (Classificação Internacional de Doenças) em reforço à Resolução CFP $n^{\circ} 01 / 2018$, do Conselho Federal de Psicologia, que orienta a atuação profissional de psicólogas/os para que travestilidades e transexualidades não sejam consideradas patológicas ${ }^{22}$.

Outro ponto que corrobora para instaurar um pânico moral advém da assimilação desta mudança no cenário esportivo ao retorno dos combates do Coliseu, revivendo aspectos sanguinários e mortais, levando a um "um verdadeiro massacre, uma violência injustificada e uma 
injustiça afrontosa", o que não condiz com a realidade atual, uma vez que existe um controle e monitoramento para permitir a participação de atletas trans, não sendo algo, portanto, permitido levianamente e desproporcionalmente como era nos espetáculos bárbaros do anfiteatro romano.

Dentre todos os projetos, este é o único a apresentar redação argumentativa em caixa alta, o que pode ser interpretado, em termos axiológicos, como uma maneira de intensificar o alarde/pânico moral que o documento tenta instaurar sobre a temática, finalizando suas ideias com o estabelecimento daquilo que se nomeia por "exemplo da humilhação" da atleta Tifanny, o que motivou as investidas de Ana Paula Henkel contra essa participação. Porém, não nos é elucidado qual foi/ é a humilhação que Tifanny promove/u ao esporte brasileiro e/ou às mulheres da Superliga Feminina de Voleibol, sendo este um subterfugio especulativo. E também, o acionamento da opinião de Ana Paula nada mais é do que o ponto de vista da própria ex-atleta, que já se demonstrou e vem se demonstrando veementemente contrária à participação de mulheres trans em competições femininas com base em argumentos, assim como os projetos, ainda inconclusivos.

Por fim, e não menos importante, vale-nos ponderar sobre a argumentação presente em todos os documentos, estaduais e federais, que buscam nos aspectos biológicos estabelecer uma verdade inquestionável sem, no entanto, atentar-se para o caráter político do discurso atrelado ao sexo e às sexualidades ao longo da história da humanidade.

As categorias biológicas sobre as quais se apoiam as distinções de sexo em nossas sociedades são objeto de debate: sexo anatômico, fisiológico, hormonal, cromossômico, genético. Vários sexos tornam-se pensáveis, nenhuma evidência natural impóe-se, mas sim um palimpsesto a ser decifrado. Algumas vezes, o mesmo indivíduo é macho, sob certos aspectos biológicos, e fêmea, sob outros [...] $\mathrm{O}$ mundo esportivo é regularmente confrontado com essa impossibilidade de decidir sobre a atribuição de um sexo biológico (Le Breton, 2014, p. 31).

Conforme afirma Le Breton (2014), com base no sexólogo Thomas Laqueur $^{23}$, na filósofa Judith Butler ${ }^{24}$ e na bióloga Fausto-Sterling ${ }^{25}$ , o sexo não se exime do universo histórico, cultural e espacial ao qual está inserido, sendo também, portanto, uma construção social. Le Breton (2014) bem lembra que, até o século XVIII, o corpo era tido como unissex, isto é, não se havia adotado até então o modelo dos dois sexos.

Apoiado em Laqueur, Le Breton explica que o sexo, historicamente, não estabelecia distinção anatômica entre homens e mulheres, sequer a diferença entre os órgãos de cada um/a deles/as. Enquanto que o sexo dos homens era externalizado, o das mulheres era, na verdade, invertido, para dentro. Assim, era o gênero que definia o sexo, não o contrário (Le Breton, 2014).

Ao longo do tempo (até o século XVII), sempre foi desnecessário centrar esforços em atribuir um "verdadeiro sexo" às pessoas. Le Breton (2014) busca em Michel Foucault ${ }^{26}$ inspiração para nos situar que, durante a Idade Média, as crianças nascidas com características 
intersexuais masculinas e femininas tinham o sexo fixado pelo pai ou padrinho de acordo com o que estes decidissem. Já no século XVIII, a medicina passa a impor o "verdadeiro sexo" com base em uma "verdade anatômica” (Le Breton, 2014, p. 30).

Com o surgimento do que Le Breton denomina de "uma diferença de espécie" (2014, p. 30), termo hierarquicamente pejorativo para designar as mulheres no século XVIII, emerge o modelo anatômico de dois sexos e a partir daí é que o sexo passa a determinar o gênero. A sede obsessiva pelas diferenças biológicas entre essas duas composições intensificou-se no século XIX, e "A ideia da continuidade dos corpos foi, então, revogada pela ideia de uma incompatibilidade radical entre os sexos" (Le Breton, 2014, p. 30).

Estes preceitos se encontram presentes em todas as esferas sociais da humanidade, incluindo-se o esporte, entretanto, por desconsiderar as discussões de poder historicamente consolidadas sobre essas categorizações, seria mais interessante desviar o olhar da participação trans em competições esportivas e passar a vislumbrar as maneiras de contornar a maneira como o esporte trata os sexos e sexualidades.

Para Camporesi (2019), só existem duas maneiras para tal: 1- Manter a divisão por sexo/gênero, respaldando o discurso da loteria genética, o que, segundo Anderson et al. (2019) nega o avanço progressivo da evolução científica; ou 2- Abandonar a divisão binária e corrigir de forma consistente e equitativa as desigualdades genéticas entre atletas por meio de três maneiras: estabelecendo categorias com base em (a) níveis hormonais e de proteínas, (b) variações biológicas e (c) modificações externas que não visem a intervir no corpo dos atletas (Camporesi, 2019). Fica a sugestão para as futuras elaborações de projetos de lei envolvendo, então, a controversa temática aqui debatida.

\section{Considerações finais}

Este estudo teve por objetivo analisar os enunciados dos seis PL's protocolados em Assembleias Legislativas nacionais que visam regulamentar a participação de atletas trans no esporte brasileiro, mais especificamente quais as bases fundamentalistas utilizadas pelos deputados autores para se posicionarem axiologicamente acerca da temática.

Evidenciamos que é comum a todos os projetos o suporte em aspectos biológicos para estabelecerem suas ementas e manterem de maneira intransigente os parâmetros esportivos de ordem cis, muito embora não se atentam para o caráter político do discurso que é e vem sendo atrelado ao sexo e às sexualidades esportivas ao longo da história da humanidade. $\mathrm{O}$ foco principal para a atuação de atletas trans, pelas propostas, resume-se ao seu sexo biológico, desconsiderando todo e qualquer processo estético e/ou hormonioterapêutico realizado.

Também, foi possível destacar que a redação dos projetos apresenta fragilidades conceituais sobre identificações e expressões de gênero e sexualidades, afirmando que atletas "nascem homens" e invalidando o 
caráter dos papéis sociais na construção e vivência do sexo masculino, por exemplo, além de não haver qualquer menção à promoção da prática esportiva por pessoas trans que não seja excludente ou exponha esse público a uma forçosa situação vexatória (respectivamente, competir em uma liga trans ou em eventos de seu sexo biológico, por exemplo).

Cabe destacar que os projetos não se alicerçam em estudos científicos sobre a temática, muito embora afirmem que a ciência já tenha comprovado a existência de vantagens fisiológicos de atletas trans se competindo com atletas cis, o que, na verdade, ainda é controverso e necessita de mais investigações empíricas para comprovar ou refutar essas hipóteses.

Por fim, destacamos ser fundamental refletir sobre a participação trans em competiçóes esportivas a partir de novas maneiras de categorização nos esportes que não apenas àquelas relacionadas ao sexo biológico do/ a atleta. Nesse sentido, desejamos que a presente pesquisa se torne mais uma potente oportunidade de questionar as normas que permeiam a esfera legislativa do/no esporte brasileiro e, assim, revitalizá-lo à luz dos princípios básicos de nossa Constituição.

\section{Referências}

Anderson, L.; Knox, T. y Heather, A. (2019) Trans-athletes in elite sport: inclusion and fairness. Emerging Topics in Life Sciences, 3, 759-762. doi: h ttps://10.1042/ETLS20180071

Bakhtin, M. (2006) Estética da Criação Verbal. [tradução feita a partir do russo; tradução Paulo Bezerra]. 5. ed. São Paulo: Martins Fontes.

Bakhtin, M. (2010) O problema do Conteúdo, do Material e da Forma na Criação Literária. En: Questôes de literatura e de estética: A Teoria do Romance. Equipe de tradução (do russo) Bernardini, A. F. et al. (Orgs.) 6. ed. São Paulo: Editora Hucitec.

Betancurt, J. O.; Zakynthinaki, M. S.; Martinez-Patiño, M. J. y Cordente, M. C. (2018) Hyperandrogenic athletes: performance differences in elite-standard $200 \mathrm{~m}$ and $800 \mathrm{~m}$ finals. Journal of Sports Sciences, 36(21), 2464-2471. doi: https://10.1080/02640414.2018.1464620

Camargo, W. X. y Kessler, C. S. (2017) Além do masculino/feminino: gênero, sexualidade, tecnologia e performance no esporte sob perspectiva crítica. Horizontes Antropológicos, 23(47), 191-225, abr. doi: https://10.1590/s0 104-71832017000100007

Camporesi, S. (2019) When does an advantage become unfair? Empirical and normative concerns in Semenya's case. Journal of Medical Ethics, 45(11), 700-704, Sep. doi: https://10.1136/medethics-2019-105532

Carvalho, P. B. (2003) O princípio da segurança jurídica em matéria tributária. Revista Da Faculdade De Direito, Universidade De São Paulo, 98, 159-180. Recuperado de http://www.revistas.usp.br/rfdusp/article/view/67584

Cellard, A. (2008) A análise documental. En: Poupart, J. et al. A pesquisa qualitativa: enfoques epistemológicos e metodológicos. Petrópolis, Vozes. pp. 295-316.

World Professional Association for Transgender Health (2012) Normas de atenção à saúde das pessoas trans e com variabilidade de gênero. Trad. Lukas 
Berredo, $7^{a}$ versão, pp. 1-123. Disponível em: < https://www.wpath.or $\mathrm{g} / \mathrm{media} / \mathrm{cms} /$ Documents/SOC\%20v7/SOC\%20V7_Portuguese.pdf >. Acesso em 27 Dez. 2019.

Devine, J. W. (2019) Gender, Steroids, and Fairness in Sport. Sport, Ethics and Philosophy, 13(2), 161-169. doi: https://10.1080/17511321.2017.14046 27

Jesus, J. G. (2012) Orientações sobre identidade de gênero: conceitos e termos. Brasília/DF, 42 p. Disponível em: http://www.diversidadesexual.com.br/wp-content/uploads/2013/0 4/G\%C3\%8ANERO-CONCEITOS-E-TERMOS.pdf . Acesso em 31 Mai. 2020.

Karkazis, K.; Jordan-Young, R.; Davis, G. y Camporesi, S. (2012) Out of Bounds? A Critique of the New Policies on Hyperandrogenism in Elite Female Athletes. The American Journal of Bioethics, 12(7), 3-16. doi: http s://10.1080/15265161.2012.680533

Karkazis, K. y Carpenter, M. (2018) Impossible "Choices": The Inherent Harms of Regulating Women's Testosterone in Sport. Journal of Bioethical Inquiry, 15(4), 579-587. doi: https://10.1007/s11673-018-9876-3

Le Breton, D. (2014) Corpo, gênero, identidade. Trad. Gercélia Batista de Oliveira Mendes. En: Ferrari, A. et al. (Orgs.). Corpo, gênero e sexualidade. Lavras: UFLA. pp. 18-34.

Santana, W. K. F. (2018) Ensino dialógico de literatura na educação básica e a formação de sujeitos críticos. En: Paiva, F. J. O. y Silveira, É. L. (Orgs). $O$ ensino na Educação Básica: diálogos entre sujeitos, saberes e experiências docentes. São Carlos: Pedro \& João Editores. pp. 411-436.

Santana, W. K. F. (2017). Heterodiscursividade e Axiologia no primeiro capítulo do Cântico Dos Cânticos. En: SINALP - Simpósio Nacional de Literatura Popular, Joao Pessoa. Cultura Popular e Cosmopolitismo Simpósio Nacional de Literatura Popular. Joao Pessoa: Mídia Editora, v. 1. p. 237-247.

Sőnksen, P. H.; Bavington, L. D.; Boehning, T.; Cowan, D.; Guha, N.; Holt, R.; Karkazis, K.; Ferguson-Smith, M. A.; Mircetic, J. y Bõhning, D. (2018) Hyperandrogenism controversy in elite women's sport: an examination and critique of recent evidence. British Journal of Sports Medicine, 52(23), 1481-1482. doi: https://10.1136/bjsports-2017-098446

Wiik, A.; Lundberg, T. R.; Rullman, E.; Andersson, D. P.; Holmberg, M.; Mandić, M.; Brismar, T. B.; Leinhard, O. D.; Chanpen, S.; Flanagan, J.; Arver, S. y Gustafsson, T. (2019) Muscle strength, size and composition following 12 months of gender-affirming treatment in transgender individuals: retained advantage for the transwomen. bioRxiv, 1-26. doi: $\mathrm{h}$ ttps://10.1101/782557

Wilson, S. L.; D’Lugos, A.; Serrano, N.; Jorgensen, T.; Harper, J.; Gaesser, G.; Dickinson, J. y Angadi, S. (2019) Cardiovascular Adaptations During the Hormonal Transition of a Male-to-Female Transgender Athlete. Medicine y Science in Sports \& Exercise, 51(6), 608. doi: https://10.1249/ 01.mss.0000562319.09371.00 


\section{Notas}

1 As terminologias abarcadas pelo guarda-chuva trans, dentre elas transgênero, transexual, travesti e andrógino serão problematizadas ao longo do texto de acordo com as proposições de Jesus (2012) e Le Breton (2014).

2 Carta na íntegra disponível em: http://politica.estadao.com.br/blogs/ana-pa ula-henkel/carta-aberta-ao-comite-olimpico-internacional

3 IOC Consensus Meeting on Sex Reassignment and Hyperandrogenism, November 2015. Disponível em https://stillmed.olympic.org/Documents/ Commissions_PDFfiles/

Medical_commission/2015-11_ioc_consensus_meeting_on_sex_reassignment_and_hyper: en.pdf Acesso em 23 mar. 2020.

4 Mais informações em: http://www.estadao.com.br/

5 Mais informações em: https://www2.camara.leg.br/camaranoticias/radio/m aterias/ESPORTES/577858-PARTICIPACAO-DE-TRANSGENEROSNO-ESPORTE-DIVIDE-OPINIOES-NA-CAMARA.html

6 Mais informações em: https://www2.camara.leg.br/atividade-legislativa/com issoes/comissoes-permanentes/cespo/noticias/para-especialistas-ciencia-ain da-nao-provou-vantagem-de-atletas-trans

7 O termo "cisgênero" designa a pessoa que se reconhece no gênero ao qual lhe foi atribuído no nascimento

8 Dentro do escopo inicial estético literário, "a axiologia faz menção às atribuições de valor(es) presentes na obra a partir das dialogizações provocadas entre autor e personagem. A valoração é um elemento importante na obra, em que o autor justapõe responsivamente os enunciados (e todos os outros elementos) à história e à memória ideológica sociais. Esse plano, chamado de axiologicamente valorativo, se faz de modo responsavelmente racional, ou seja, é o ponto nevrálgico em que a obra mantém contato pleno com outras vozes que a atravessam, e aí reside seu valor interdiscursivo" (Santana, 2017, p. 237).

9 Este texto se encontra na Coletânea Estética da criação verbal (2006), versão traduzida do russo para o Português por Paulo Bezerra.

10 Informações disponibilizadas pelo portal online da Assembleia Legislativa do Estado de São Paulo. Disponível em: https://www.al.sp.gov.br/deputado/?m atricula $=300609$. Acesso em 14 fev. 2020.

11 Cálculo efetuado com base no término do ano de 2020.

12 Disponível em: https://www.al.sp.gov.br/propositura/?id=1000261787. Acesso em: 14 fev. 2020.

13 Disponível em: http://www3.alerj.rj.gov.br/lotus_notes/default.asp?id=144 \&url=L3NjcHJvMTkyMy5uc2YvMThjMWRkNjhmOTZiZTNINzgzMj U2NmVjMDAxOGQ4MzMvMmVhZGU3M2E2NmZmNDMyYzgzMj U4M2QxMDA2NTg4NjU/T3BlbkRvY3VtZW50. Acesso em 14 fev. 2020.

14 Disponível em: https://sapl.al.am.leg.br/media/sapl/public/materialegislativ a/2019/133747/20190410084142.pdf Acesso em 14 fev. 2020

15 Constituição da República Federativa do Brasil de 1988. Disponível em: http: //www.planalto.gov.br/ccivil_03/constituicao/constituicao.htm. Acesso em 25 fev. 2020.

16 Disponível em: https://www.camara.leg.br/proposicoesWeb/prop_mostrari ntegra;jsessionid=6A12135A3B15D52ED72AA388232B08CA.proposicoe sWebExterno1 codteor $=1739697 \&$ filename $=P L+2596 / 2019$. Acesso em 14 fev. 2020.

17 Disponível em: https://www.camara.leg.br/proposicoesWeb/prop_mostrar integra? codteor $=1741995 \&$ filename $=\mathrm{PL}+2639 / 2019$. Acesso em $14 \mathrm{fev}$. 2020.

18 Disponível em: https://www.camara.leg.br/proposicoesWeb/prop_mostrar integra? codteor $=1730814 \&$ filename $=\mathrm{PL}+2200 / 2019$. Acesso em $14 \mathrm{fev}$. 2020 . 
19 Não é só Tifanny: ainda longe da Superliga, clubes consultam CBV sobre inscrições de atletas trans. Disponível em: https://globoesporte.globo.com/vo lei/noticia/nao-e-so-tifanny-ainda-longe-da-superliga-clubes-consultam-cbv -sobre-inscricoes-de-atletas-trans.ghtml. Acesso em 25 fev. 2020.

20 No texto da World Professional Association for Transgender Health (2012), os/as autores/as descrevem detalhamento o panorama geral dos riscos médicos da terapia hormonal para homens e mulheres, no anexo B do documento, páginas 108-114. Recomendamos a leitura para maior aprofundamento.

21 Gender incongruence. Available in: https://icd.who.int/browse11/l-m/en\#/ http\%3a\%2f\%2fid.who.int\%2ficd\%2fentity\%2f411470068. Acess in 25 feb. 2020.

22 RESOLUÇÃO № 1, DE 29 DE JANEIRO DE 2018 - Estabelece normas de atuação para as psicólogas e os psicólogos em relação às pessoas transexuais e travestis. Disponível em: https://site.cfp.org.br/wp-content/uploads/2018 /01/Resolu\%C3\%A7\%C3\%A3o-CFP-01-2018.pdf. Acesso em 25 fev. 2020.

23 Filósofo, historiador e biólogo, Laqueur nasceu na Turquia, leciona História na UCLA e é autor da obra "Inventando o Sexo: Corpo e Gênero dos Gregos a Freud", onde discute sobre a variação histórica da ideia de sexo no pensamento médico, filosófico e político desde o século XVIII até os dias atuais. Defende a teoria de que as diferenças estabelecidas entre os sexos, bem como as desigualdades culturais de gênero não são meros frutos do acaso biológico, mas sim oriundos de crenças científicas, políticas, filosóficas e religiosas que constroem os seres humanos.

24 Filósofa pós-estruturalista estadunidense, Butler é conhecida por ser uma das principais teóricas feministas da contemporaneidade. Professora da University of California, vem desde os anos 1990 contribuindo cientificamente para os debates sobre as teorias queer, estudos de gênero, psicanálise, poder e processos de subjetivação, guerra, luto e violência política, estado de exceção, resistências etc.

25 Anne Fausto-Sterling é professora de biologia e estudos de gênero de Nancy Duke Lewis no Departamento de Biologia Molecular e Celular e Bioquímica da Brown University. Dentre suas principais teorizações, Anne problematiza como a medicina veio ao longo dos anos utilizando-se de parâmetros culturalmente instituídos para adequar corpos humanos em divisões estanques de sexo e gênero, denunciando um caráter ultrapassado dessas ordenaçỗes e investigando o conceito de sexo/gênero como categorias inseparáveis. Em sua obra The Five Sexes, criou o conceito de cinco sexos para se referir aos genótipos $\mathrm{XX}, \mathrm{XY}, \mathrm{XXY}, \mathrm{XXX}$ e XYY, numa espécie de crítica à interpretação binária de releitura de corpos como homens e mulheres, apenas.

26 Filósofo francês, desenvolveu teorias que problematizam as relações entre saber, poder e conhecimento e a maneira que essa tríade é utilizada para controlar a sociedade através de suas instituições. Dentre suas principais obras, estão A Arqueologia do Conhecimento, Vigiar e Punir, e História da Sexualidade, onde teceu suas opiniões com base em métodos arqueológicos e genealógicos da leitura histórica das sociedades, debatendo, principalmente, sobre como o poder se constitui na vida humana e suas variadas facetas para estabelecer discursos de estabelecimento, controle e vigilâncias sociais. 